\title{
Morphological heterogeneity in childhood B cell acute lymphoblastic leukaemia
}

\author{
K AL-RUBEI, PE ROSE, FGH HILL \\ From the Haematology Department, The Children's Hospital, Ladywood Middleway, Ladywood, \\ Birmingham B16 8ET
}

SUMMARY Considerable heterogeneity of lymphoblast morphology in childhood B cell acute lymphoblastic leukaemia has been observed. One case showed unusual monocytic features and emphasised the need for marker studies in the accurate definition of acute lymphoblastic leukaemia phenotypes. B cell acute lymphoblastic leukaemia is rare but may have been previously underestimated by morphological misinterpretation. Further information is required to determine if the different morphological features of this condition are of clinical and prognostic importance.

In 1976 the French-American-British Cooperative Group classified acute lymphoblastic leukaemia into three morphology groups, $\mathrm{L}_{1}, \mathrm{~L}_{2}$, and $\mathrm{L}_{3}$, using Romanowski stained films.' Different observers consistently identified $\mathrm{L}_{3}$ lymphoblasts but considerable variation between observers occurred in assigning lymphoblasts to $\mathrm{L}_{1}$ and $\mathrm{L}_{2}$ categories. $\mathrm{L}_{3}$ morphology has subsequently been reported as characteristic of childhood $B$ cell acute lymphoblastic leukaemia (B ALL). ${ }^{2}$ There is otherwise a poor correlation between lymphoblast morphology and immunological phenotype. We report four cases of B ALL in children. The morphology displayed is more varied than previously recognised.

\section{Material and methods}

Blood was taken by venepuncture and placed in plastic tubes containing lithium heparin (LIP Equipment Services Ltd). Marrow was aspirated and placed immediately into lithium heparin tubes containing tissue culture medium (RPMI 1640 Gibco Europe Ltd) or used to make direct films, which were subsequently stained with Wright's stain for diagnostic morphological examination.

For lymphocyte separation blood was diluted with an equal volume of tissue culture medium at $37^{\circ} \mathrm{C}$ and layered gently on to $3 \mathrm{ml}$ of Lymphoprep (Nyeguard and Co, AS Oslo) in a conical centrifuge tube (Sterilin Ltd, England) and centrifuged at 400 $g$ for 25-30 min. The interphase containing the mononuclear cells was collected and washed three

Accepted for publication 9 August 1984 times with tissue culture medium at $37^{\circ} \mathrm{C}$. The washed cells were resuspended in tissue culture medium containing $5 \%$ heat inactivated fetal calf serum (Sera-Lab Ltd, Sussex, England) in a final concentration of $2.5 \times 10^{6} \mathrm{cells} / \mathrm{ml}$.

Surface membrane marker studies were pers formed in our own laboratory (see method) unless otherwise stated. The percentage of $T$ cells was determined by the spontaneous formation of rosettes with sheep erythrocytes ${ }^{3}$ and that of B cells by demonstrating surface immunoglobulin using fluorescein conjugated antihuman immunoglobulin (Wellcome Reagents Ltd, Beckenham, England). Monoclonal antisera OKTll (Ortho Diagnostics Systems, New Jersey, USA) and B1 and I2 (Coulter Electronics Ltd, Luton, England) for the detection of the B1 antigen and Ia like or HLA-DR antigens, respectively, were used according to the manufacturer's instructions.

\section{PATIENTS}

Table 1 shows the clinical and haematological features of the four patients at presentation. Additional information about these patients is as follows.

Patient 1 died shortly after admission with severe metabolic complications, having also developed a pulmonary fat embolism. Postmortem examination showed diffuse involvement by lymphoblasts of bone marrow, lymph nodes, thymus, lungs, liver, spleen, kidneys, testes, pancreas, and parotids. Histological examination of these organs showed a "starry sky" appearance as seen in Burkitt's lymphoma. 
Table 1 Presenting clinical features and haematological findings of four cases of B cell acute lymphoblastic leukaemia in childhood

\begin{tabular}{|c|c|c|c|c|}
\hline $\begin{array}{l}\text { Patient no } \\
\text { Sex } \\
\text { Age (yr) } \\
\text { Lymphadenopathy }\end{array}$ & $\begin{array}{c}1 \\
\text { Boy } \\
3 \\
\text { Axillae }\end{array}$ & $\begin{array}{l}2 \\
\text { Girl } \\
13 \\
\text { Nil }\end{array}$ & $\begin{array}{l}3 \\
\text { Girl } \\
8 \\
\text { Axillae Cervical } \\
\text { Inguinal }\end{array}$ & $\begin{array}{l}\quad 4 \\
\text { Girl } \\
10 \text { months } \\
\text { Axillae Cervical } \\
\text { Inguinal }\end{array}$ \\
\hline $\begin{array}{l}\text { Jaundice } \\
\text { Hepatomegaly (cm) } \\
\text { Splenomegaly } \\
\text { Ascites } \\
\text { Other features }\end{array}$ & $\begin{array}{l}\text { Nil } \\
5 \\
6 \\
\text { Nil }\end{array}$ & $\begin{array}{l}\text { Nil } \\
\text { Nil } \\
\text { Nil } \\
+++ \\
\text { Renal enlargement }\end{array}$ & $\begin{array}{l}++ \\
4 \\
6 \\
+++ \\
\text { CNS disease }\end{array}$ & $\begin{array}{l}\text { Nil } \\
5 \\
\text { Nil } \\
\text { Nil } \\
\text { Necrotic vulva }\end{array}$ \\
\hline $\begin{array}{l}\text { Haemoglobin concentration } \\
(\mathrm{g} / \mathrm{dl})\end{array}$ & & 10.8 & $11 \cdot 3$ & $8 \cdot 1$ \\
\hline $\begin{array}{l}\text { Platelet count }\left(\times 10^{y} / 1\right) \\
\text { White cell count }\left(\times 10^{y} / 1\right) \\
\text { Blast cell count }\left(\times 10^{\prime} / 1\right) \\
\text { Histology }\end{array}$ & $\begin{array}{l}35 \\
35 \cdot 5 \\
1.7 \\
\text { Diffuse organ } \\
\text { involvement* }\end{array}$ & $\begin{array}{l}45 \\
4 \cdot 2 \\
0 \cdot 3 \\
\text { Ovarian tumour at } \\
\text { laparotomy }\end{array}$ & $\begin{array}{c}200 \\
4 \cdot 2 \\
0 \\
\mathrm{Nil}\end{array}$ & $\begin{array}{r}90 \\
104 \\
104 \\
\text { Nil }\end{array}$ \\
\hline
\end{tabular}

*Histological pattern identical to that of Burkitt's lymphoma.

$++=$ moderate; $+++=$ gross.

Patient 2 was admitted with a normal blood count in acute renal failure. When peritoneal dialysis was started, severe intra-abdominal haemorrhage occurred. At laparotomy a large ovarian tumour was found to be the site of haemorrhage. Histological examination of the excised tumour showed a "starry sky" appearance consistent with a Burkitt's lymphoma. The aspirated marrow showed replacement of normal haemopoiesis by $\mathrm{L}_{3}$ type lymphoblasts. The patient died in acute renal failure with peritonitis after eight days of induction chemotherapy.

Patient 3 developed severe metabolic complications with a rapidly rising blood urea concentration, hypocalcaemia, hyperphosphataemia, and hyperglycaemia. Paroxysmal episodes of hypertension were followed by a large non-fatal intracranial haemorrhage, which subsequently required surgical evacuation. At this stage the patient entered remission, but unfortunately she was left with a hemiplegia and partial cortical blindness. She subsequently developed a meningeal relapse, from which she died.

Patient 4 contrasted with the other cases by presenting with a high white cell count (see Table 1) and by having no metabolic problems during induction. A necrotising pseudomonas infection of the vulva was successfully treated with antibiotics and white cell infusions. She remains in remission 18 months after diagnosis following treatment according to the UKALL VIII protocol for children with acute lymphatic leukaemia.

\section{Results}

The morphological appearances of the blast cells from each patient are shown in Figs. 1-4. The large blast cells from patient 1 (Fig. 1) show the typical features of $\mathrm{L}_{3}$ lymphoblasts, intensely basophilic cytoplasm due to the high content of RNA, and the prominent vacuolation of the lymphoblasts. Those from patient 2 (Fig. 2) also fulfil the criteria for $\mathrm{L}_{3}$ type. The blast cells from patient 3 (Fig. 3), although displaying a deeply basophilic cytoplasm, lack the characteristic vacuolation of $L_{3}$ cells; therefore, the $B$ cell nature of the acute lymphoblastic leukaemia could have been overlooked. The morphology of the blast cells from case 4 (Fig. 4) shows no $L_{3}$ features; there is abundant pale blue/grey. cytoplasm with minimal vacuolation and a large oval nucleus with open chromatin and prominent nucleoli. Our first impression was that these cells morphologically resembled monoblasts. Cytochemical esterase activity, a characteristic of monoblasts, ${ }^{4}$ was absent.

Surface marker studies confirming the B cell nature of the four cases are summarised in Table 2.

Table 2 Presenting lymphocyte surface marker studies

\begin{tabular}{lllll}
\hline Patient no & ER (\%) & SMIg (\%) & BI (\%) & I2 (\%) \\
\hline 1 & 41 & 25 & NT & NT \\
2 & 3 & 80 & 83 & NT \\
3 & 55 & 50 & 55 & 80 \\
4 & 2 & 98 & NT & NT \\
\hline
\end{tabular}

$\mathrm{ER}=$ erythrocyte rosettes.

SMIg = surface immunoglobulin.

NT $=$ not tested.

Table 3 Extended lymphocyte surface marker studies* on lymphoblasts of patient 4

\begin{tabular}{lll}
\hline$T$ cell markers & $B$ cell markers & Early lymphoid markers \\
\hline Sheep rosettes <1\% & Anti IgG 70\% & Anti-common ALL 0\% \\
Anti-T 0\% & $\begin{array}{l}\text { Anti } \kappa 74 \% \\
\text { Anti } \lambda \text { 0\% }\end{array}$ & Tdt -ve \\
& HLA-DR 56\% & \\
\hline
\end{tabular}

*From Dr Greaves, The Imperial Cancer Research Institute, London. 

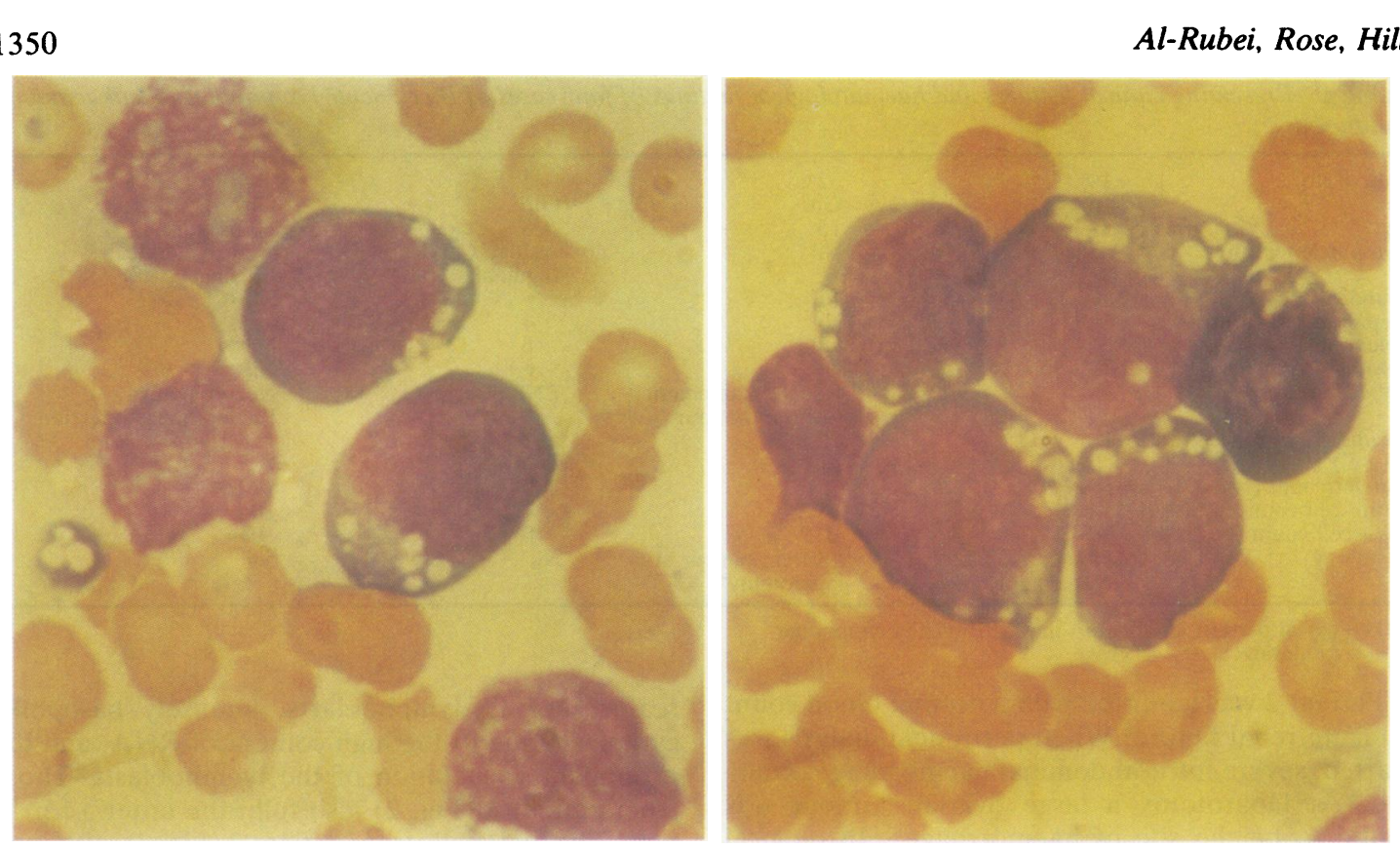

Fig. 1

Fig. 2

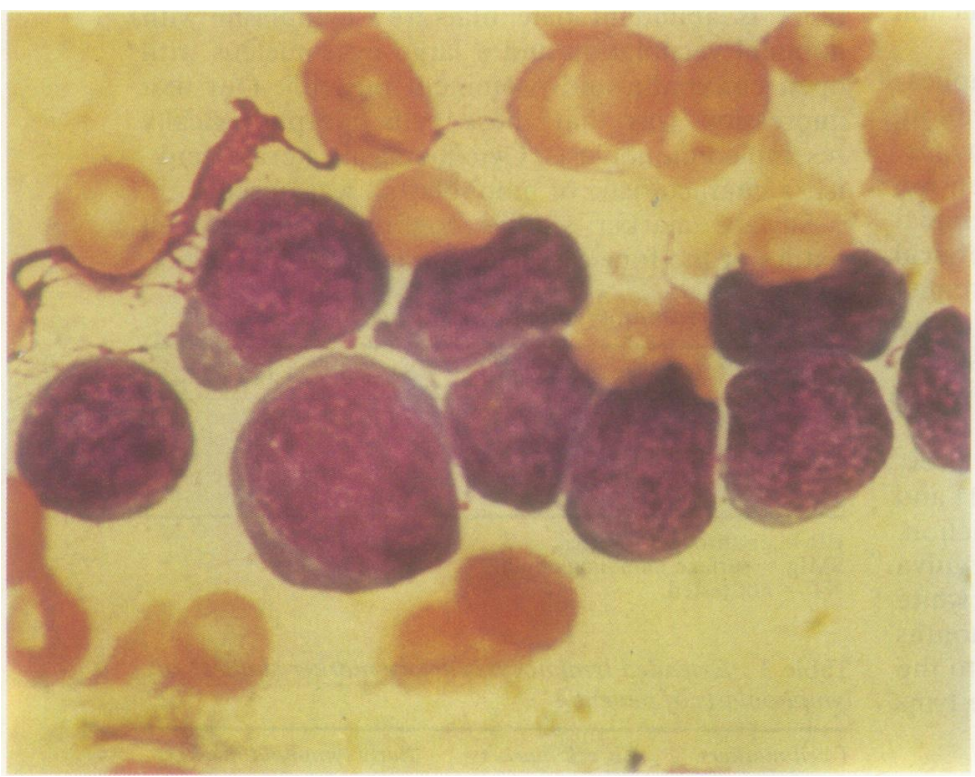

Fig. 3

Fig. 4

Figs. 1-4 The morphological appearances of the blast cells from patients 1-4. 
In view of the atypical morphology in patient 4 and the finding of surface immunoglobulin on $98 \%$ of cells, the marker studies were repeated and extended by Dr M Greaves at the Imperial Cancer Research Institute. These results confirmed the monoclonal B cell phenotype of the blast cells (Table 3).

\section{Discussion}

Although the lymphoblast morphology is often of $\mathrm{L}_{3}$ FAB type in adults with B ALL, ${ }^{5}$ heterogeneous morphology with cases of $L_{1}$ and $L_{2}$ blast cells has been reported. ${ }^{6}$ Cases with atypical morphology have included patients with acute leukaemic transformation to B ALL from chronic lymphocyte leukaemia ${ }^{7}$ and secondary marrow involvement with non-Hodgkin's lymphomas.

In children, B ALL represents only $1-2 \%$ of cases of acute lymphoblastic leukaemia. ${ }^{8}$ Patients with $\mathrm{L}_{3}$ morphology have been reported consistently as having B ALL. ${ }^{2}$ Lymphoblasts of $\mathrm{L}_{3}$ type are not, however, diagnostic of B ALL in children. Between the years 1976 and 1983 we have seen five cases with $L_{3}$ lymphoblasts that have typed as non- $B$, non- $T$ acute lymphoblastic leukaemia, and similar cases have been reported by others. ${ }^{9}$ The marrow cytology and trephine biopsy histology of $\mathrm{L}_{3}$ cells is indistinguishable from those described in cases of Burkitt's lymphoma. ${ }^{510}$ In contrast to the African cases of Burkitt's lymphoma," cases from non-endemic Europe $^{12}$ and North America ${ }^{13}$ often have marrow involvement. The $\mathrm{L}_{3}$ morphology of marrow lymphoblasts seen in patients 1 and 2 was accompanied by histological features indistinguishable from Burkitt's lymphoma on lymph node and ovarian tissue. The morphological and histological features of these two cases are representative of the majority of children with B ALL.10

In contrast, the lymphoblast morphology in patient 4 has not been reported previously in association with $B$ cell phenotype. The morphology of these cells is more characteristic of acute monocytic leukaemia. Two previously reported cases of acute monocytic leukaemia in infancy, ${ }^{14}$ however, had characteristic intracytoplasmic esterase activity present. In both these cases surface immunoglobulin was detected, but unlike our patient (see below) $\kappa$ and $\lambda$ light chains were found. This observation is consistent with the passive absorption of immunoglobulin from serum, rather than being the product of a neoplastic clone. In case 4 only $\kappa$ light chains were shown, which confirms the monoclonal B cell phenotype of the leukaemia.

Surface immunoglobulin was shown in all four patients, with cells from patients 1 and 3 initially showing a population of positive $\mathrm{T}$ cell markers. Serial analysis of markers on marrow aspirates from patient 3 before chemotherapy showed a considerable reduction in OKT11 positive cells from $26 \%$ to $11 \%$ and a further increase in all $B$ cell markers after $24 \mathrm{~h}$. Analysable chromosomal spreads were unfortunately obtained from case 1 only and in this patient's lymphoblasts the $14 \mathrm{q}^{+}$anomaly previously reported with B ALL and Burkitt's lymphoma was found. ${ }^{15}$ Further differentiation of cases of B ALL in children based on blast cell morphology may be of clinical and therapeutic importance. Recognition of cases with and without $\mathrm{L}_{3}$ morphology may be important. A low or absent blast cell count in the blood is usual in B ALL (the so called Burkitt's lymphoma cases with marrow disease). Cases 1 and 2 with $\mathrm{L}_{3}$ cells had low blast cell counts in the blood while blast cells were not seen in the blood from patient 3 . In contrast, patient 4 , with morphological features more like a monocytic leukaemia, had a high blood blast cell count $\left(104 \times 10^{9} / 1\right)$.

Furthermore, patients with $\mathrm{L}_{3}$ morphology are at risk of severe metabolic complications secondary to acute tumour lysis, particularly during induction chemotherapy. ${ }^{16}$ Such features were noted in our first three patients, but patient 4 , despite the initial high white cell count, encountered no such problems. This 10 month old baby girl responded well to induction chemotherapy with prednisolone and vincristine and remains in complete remission 18 months later on a UKALL VIII maintenance regimen.

In conclusion, we emphasise the importance of accurate identification of the lymphoblast phenotype in all cases of childhood leukaemia. Further cases with B cell phenotype and atypical morphological features may subsequently be recognised. The clinical and prognostic features of these cases may be different from previously reported cases of B ALL in childhood.

We thank Dr Mann for permission to include data on her patients in this study, Dr MG Greaves for extending the marker studies in patient 4 , Dr AH Cameron for histopathology data, and Mrs P Mann for typing the manuscript.

\section{References}

' Bennett JM, Catovsky D, Daniel MT, et al. Proposals for the classification of the acute leukaemias. $\mathrm{Br} J$ Haematol 1976;33:451-8.

2 Coccia P, Miller DR, Kersey JH, et al. Relationship of blast cell surface markers and morphology (FAB classification) in childhood acute lymphocytic leukaemia. (Abstract) Blood 1979; 54: (suppl 1) 182a.

${ }^{3}$ Waller CA, MacLennan ICM. Analysis of lymphocytes in blood and tissues. In: Thompson RA, ed. Techniques in clinical 
immunology. Oxford: Blackwell Scientific Publications, 1977:170-200.

4 Yam L, Li CY, Crosby WH. Cytochemical identification of monocytes and granulocytes. Am J Clin Pathol 1971;55:28390.

${ }^{5}$ Magrath I, Zeigler JL. Bone marrow involvement in Burkitt's lymphoma and its relationship to acute B-cell leukaemia. Leukaemia Research 1979;4:33-59.

- Brouet JC, Preud'homme JL, Seligmann M. The use of B and T membrane markers in the classification of human leukaemias with special reference to acute lymphoblastic leukaemia. Blood Cells 1975;1:81-4.

' Brouet JC, Preud' homme JL, Bernard J. Blast cells with monoclonal surface immunoglobulin in two cases of acute blast crisis supervening on chronic lymphocytic leukaemia. $\mathrm{Br}$ Med $\mathrm{J}$ 1973;iv: $23-4$.

${ }^{8}$ Chessells M. Acute lymphoblastic leukaemia. Sem Haematol 1982;19:155-71.

${ }^{4}$ Belpomme D, Mathe G, Davies AJ. Clinical significance and prognostic value of the T-B immunological classifications of human primary acute lymphoid leukaemias. Lancet 1977;i:555-8.

${ }^{10}$ Flandrin G, Brouet JC, Daniel MT, et al. Acute leukaemia a study of six cases with special reference to lymphocyte surface markers. Blood 1975;45: 183-8.
" Burkitt DP, O' Conor GT. Malignant lymphoma in African children. A clinical syndrome. Cancer 1961;14:258-69.

${ }^{12}$ Brealy RC, Lister TA, Whitehouse JMA, Stansfield AG. Burkitt's lymphoma in British adults. Clinical features and response to chemotherapy. Br J Cancer 1977;35:484-7.

${ }^{13}$ Arseneau JC, Canellos GP, Banks PM et al. American Burkitt's lymphoma: a clinicopathologic study of $\mathbf{3 0}$ cases II. Pathological correlations. Am J Med 1975;58:322-9.

${ }_{14}$ Raney BR, Mohanakumar T, Metzgar RS, et al. Acute monocytic leukaemia in two infants: clinical, histochemical and immunological investigations. Leukaemia Research 1979;4:61-7.

is Berger R, Bernheim A, Brouet JC, Daniel MT, Flandrin GT. $t(8: 14)$ Translocation on a Burkitt's type of lymphoblastic leukaemia $\left(\mathrm{L}_{3}\right)$. Br J Haematol 1979;43:87-90.

${ }^{16}$ Cohen LF, Balow JE, Magrath IT, Poplack DG, Ziegler JC. Acute tumour lysis syndrome: a review of 37 patients with Burkitt's lymphoma. Am J Med 1980;68:486-91.

Requests for reprints to: Dr PE Rose, Haematology Department, The Children's Hospital, Ladywood Middleway, Ladywood, Birmingham B16 8ET, England. 